\title{
ANALISIS KEUANGAN INKLUSIF: STUDI KASUS DAERAH ISTIMEWA YOGYAKARTA
}

\author{
Atikah, Ahmad Ma'ruf \\ Fakultas Ekonomi, Universitas Muhammadiyah Yogyakarta \\ Jalan Lingkar Selatan, Tamantirto, Kasihan, Bantul, Yogyakarta 55183 \\ E-mail korespondensi: atikahuntet@yahoo.co.id
}

Naskah Diterima: November 2015; Disetujui: Maret 2016

\begin{abstract}
This study aims to analyze of financial inclusion in special region of Yogyakarta. Financial inclusion is a means to promote financial sector especially for easy banking services and financial access for people. The level of financial inclusion each district in special region of Yogyakarta will be measured by using the index of financial inclusion. Factors that affecting of financial inclusion that is GRDP, Literacy and Road Ratio, that will be analyze using a panel regression with cross section of 5 districts/cities from 20042013. The results show that the level of financial inclusion in special region of yogyakarta is classified as low, indicated by the value of financial inclusion index less than 0.3. Almost all districts/cities in special region of Yogyakarta have low level of financial inclusion, except Yogyakarta city. GRDP positively affect the level of financial inclusion in special region of Yogyakarta. While the Literacy rate and the Road Ratio negative affect of financial inclusion in special region of Yogyakarta.
\end{abstract}

Keywords: financial inclusion, GRDP, Literacy, road ratio, data panels JEL Classification: F43, P45

Abstrak: Penelitian ini bertujuan untuk menganalisis Keuangan Inklusif di Daerah Istimewa Yogyakarta. Keuangan Inklusif merupakan salah satu cara untuk memasyarakatkan sektor keuangan khususnya mempermudah layanan perbankan dan akses keuangan bagi masyarakat. Tingkat keuangan inklusif masing-masing kabupaten/kota di Daerah Istimewa Yogyakarta akan dihitung dengan menggunakan Indeks Keuangan Inklusif. Faktor yang digunakan dalam mempengaruhi Keuangan Inklusif antara lain PDRB, Angka Melek Huruf dan Rasio Jalan yang akan dianalisis menggunakan data panel dengan cross section 5 kabupaten/kota dan tahun dasar analisis 2004-2013. Hasil penelitian ini menunjukkan bahwa tingkat Keuangan Inklusif di Daerah Istimewa Yogyakarta tergolong rendah, yang ditunjukkan dengan nilai indeks keuangan inklusif kurang dari 0,3. Hampir seluruh kabupaten/kota di Daerah Istimewa Yogyakarta memiliki tingkat keuangan inklusif rendah, kecuali Kota yogyakartakarta. PDRB berpengaruh positif terhadap Keuangan Inklusif di Daerah Istimewa Yogyakarta. Sedangkan Angka Melek Huruf dan Rasio Jalan berpengaruh negatif terhadap keuangan inklusif di Daerah Istimewa Yogyakarta.

Kata kunci: keuangan inklusif, PDRB, melek huruf, rasio jalan, data panel Klasifikasi JEL: F43, P45 


\section{PENDAHULUAN}

Indonesia merupakan negara dengan pertumbuhan ekonomi tinggi, bahkan mendapat apresiasi dari dunia internasional karena mendapat peringkat ke 3 sebagai negara yang tahan terhadap krisis moneter 2008 (Setiawan, 2015). Pertumbuhan ekonomi yang berkualitas sejatinya merupakan pertumbuhan yang mampu menciptakan pengentasan kemiskinan, memperluas kesempatan kerja dan pemerataan pendapatan. Namun pertumbuhan ekonomi Indonesia yang tinggi ini justru diikuti dengan meningkatnya kondisi pengangguran dan kemiskinan. Sebagaimana salah satu tujuan dari Millenium Development Goal (MDG) bahwa pada tahun 2015 penduduk miskin di dunia pada umumnya dan Indonesia berkurang menjadi setengahnya (Sanjaya, 2014). Namun demikian fakta yang ada menunjukkan bahwa penurunan jumlah penduduk miskin di Indonesia sampai dengan tahun 2013 masih belum seperti yang diharapkan.

Laju pertumbuhan perekonomian Indonesia terus meningkat dari 4,9 persen pada tahun 2003 menjadi lebih dari 5,7 persen pada tahun 2013. Selain pertumbuhan ekonomi yang terus meningkat, perubahan angka kemiskinan yang ditunjukan oleh besarnya tingkat penduduk miskin di Indonesia juga menunjukan hal yang positif. Sepanjang tahun 2003 sampai dengan 2013 persentase jumlah penduduk miskin di Indonesia terus berkurang dari 17,42 persen menjadi 11,47 persen (BPS, 2015). Sementara itu pada saat yang sama pertumbuhan ekonomi di Indonesia ternyata menimbulkan kesenjangan pendapatan yang tinggi. Angka rasio Gini pada tahun 2012 mencapai 0,410 dan meningkat menjadi 0,413 pada tahun 2013, angka ini merupakan angka yang cukup tinggi dalam sepuluh tahun terakhir. Kedua fakta diatas menunjukkan adanya sesuatu yang perlu mendapatkan perhatian yang lebih terkait dengan proses dan pelaksanaan pembangunan ekonomi di Indonesia. Kondisi ini juga menunjukkan bahwa kesejahteraan masyarakat Indonesia khususnya dalam hal ekonomi masih rendah.

Menurut Wibowo (2014) dalam Setiawan (2015) bahwa salah satu penyebab kurangnya kesejahteraan masyarakat Indonesia adalah tingkat literasi keuangan masyarakat Indonesia yang sangat rendah. Tingkat literasi keuangan masyarakat Indonesia masih rendah dibandingkan dengan negara lainnya seperti Singapura, Malaysia, dan Thailand. Tingkat literasi keuangan masyarakat Malaysia mencapai 66 persen, Singapura mencapai 98 persen, sedangkan Thailand mencapai angka 73 persen, sementara Indonesia masih pada angka 28 persen. Salah satu faktor penyebab rendahnya literasi keuangan tersebut adalah kondisi geografis Indonesia yang pada umumya merupakan daerah kepulauan dan sekitar 60 persen masyarakat berada pada daerah pedesaan sehingga mengahambat akses terhadap layanan jasa keuangan. Untuk mengatasi keterbatasan akses layanan jasa keuangan tersebut, maka muncul suatu program perluasan akses layanan keuangan yang disebut dengan keuangan inklusif. Keuangan inklusif mempromosikan akses dan penggunaan layanan keuangan berkualitas tinggi secara global, khususnya di antara orangorang miskin (Steelyana, 2013)

Keuangan inklusif menjadi salah satu agenda penting dalam dunia internasional. Forum internasioanl seperti G20, APEC, AFI, OECD, dan ASEAN secara intensif melakukan pembahasan mengenai keuangan inklusif. Keuangan inklusif juga telah menjadi prioritas dari pada pemerintah Indonesia. Pada bulan juli 2012, Bank Indonesia bekerjasama dengan Sekretariat Wakil Presiden-Tim Nasional Pencapaian Penanggulangan Kemiskinan (TNP2K) dan Badan Kebijakan FiskalKementerian Keuangan mengeluarkan Strategi Nasional Keuangan Inklusif. Salah satu tujuan dari strategi tersebut adalah menjadikan strategi nasional keuangan inklusif sebagai bagian dari strategi besar pembangunan ekonomi, penanggulangan kemiskinan, pemerataan pendapatan dan stabilitas sistem keuangan. Keuangan yang semakin inklusif dapat memberikan akses terhadap jasa keuangan yang lebih luas bagi setiap penduduk, terutama kelompok miskin dan menengah yang memiliki keterbatasan akses terhadap layanan keuangan.

$$
\text { Hasil penelitian Sanjaya }
$$

menjelaskan bahwa keuangan inklusi di Indonesia dikategorikan rendah. Menurut 
Ummah (2015) rata-rata indeks keuangan inklusif antar provinsi di Indonesia berkisar antara 0,1-0,33 kecuali provinsi Jakarta yang tergolong tinggi yang mencapai 0,8 . Daerah Istimewa Yogyakarta masuk dalam tingkat inklusi rendah bersama dengan 31 provinsi lainnya. Hal tersebut dikarenakan masyarakat miskin belum sepenuhnya bersentuhan dengan sektor keuangan formal atau partisipasi masyarakat yang masih rendah terhadap jasa keuangan formal. Hal ini dapat dilihat dari tiga sisi yaitu aksesabilitas, ketersediaan dan penggunaan.

Keuangan inklusif di pengaruhi berbagai macam faktor, diantaranya adalah PDRB, Angka Melek Huruf dan Rasio Jalan. PDRB merupakan nilai akhir pasar dari barang dan jasa akhir yang dihasilkan dari suatu perekonomian selama kurun waktu tertentu dan biasanya 1 tahun. PDRB dihitung melalui 3 pendekatan yaitu pendekatan pengeluaran, produksi dan pendapatan. Angka Melek Huruf mencerminkan proporsi penduduk yang bisa membaca dan menulis huruf pada suatu daerah tanpa perlu mengerti apa yang ditulis dan dibaca. Jalan sebagai salah satu infrastruktur fisik yang dibutuhkan dalam pembangunan dan merupakan salah satu transportasi darat yang memegang peranan penting dalam sektor perhubungan terutama untuk menunjang pertumbuhan ekonomi dan mengembangkan potensi daerah.

Irmawati dan Setyani (2013) meneliti tentang penerapan model keuangan inklusif pada UMKM berbasis pedesaan di Kabupaten Klaten. Metode yang digunakandalam penelitian ini yaitu analisis deskriptif dan analisis SWOT. Hasil penelitian ini menunjukkan bahwa model keuangan inklusif untuk UMKM Batik di Kabupaten Klaten yaitu masuknya lembaga keuangan dalam segi permodalan yaitu berbentuk kredit bunga rendah dan KUR, yang selanjutnya dilakukan pendampingan dari lembaga keuangan. Sedangkan dari segi pemasaran, diperlukan adanya pendampingan intensif, pengikutsertaan pameran batik serta iklan.

I Made Sanjaya (2014) melakukan penelitian tentang keuangan inklusif dan pertumbuhan inklusif sebagai strategi pengentasan kemiskinan di Indonesia periode 2007-2010.
Metode yang digunakan dalam penelitian ini menggunakan konsep fungsi peluang sosial (Social Opportunity Function) yang hampir sama dengan fungsi kesejahteraan sosial untuk model pembentukan indeks pertumbuhan inklusif. Sedangkan untuk menganalisis peran keuangan inklusif terhadap pertumbuhan inklusif di Indonesia digunakan model panel data. Dalam penelitian ini Indeks Pertumbuhan Inklusif (IPI) digunakan sebagai variabel dependen, sedangkan variabel independennya menggunakan Indeks Keuangan inklusif (IIK), Indeks Harga Konsumen (IHK), rasio penyaluran kredit mikro dan menengah terhadap PDRB dan Indeks Pembangunan Manusia. Hasil dari penelitian ini menyimpulkan bahwa partisipasi seluruh masyarakat dalam proses pertumbuhan menjadi bagian dari pertumbuhan inklusif yang multidimensi. Penyediaan akses layanan dan jasa-jasa sektor keuangan yang terjangkau bagi masyarakat miskin secara langsung membuat kelompok masyarakat miskin ikut berpartisipasi dan menjadi agen pertumbuhan ekonomi sehingga menciptakan pertumbuhan yang inklusif yang dalam jangka panjang dapat mengurangi tingkat kemiskinan di Indonesia.

Moh. Agung Setiawan (2015) menganalisis keterkaitan keuangan inklusif terhadap perilaku keuangan personal masyarakat di wilayah kota dan kabupaten provinsi jawa timur. Moetode yang digunakan dalam penelitian ini adalah regresi linear sederhana dengan menggunakan aplikasi Statistical Product and Service Solution (SPSS). Adapun variabel yang digunakan dalam penelitian ini adalah Indeks Keuangan inklusif sebagai variabel bebas dan Perilaku Keuangan Personal sebagai variabel terikat. Untuk menghitung indeks keuangan inklusif digunakan beberapa indikator perbankan yaitu penetrasi perbankan, aksesibilitas jasa keuangan, dan penggunaan rekening perbankan. Untuk mengukur perilaku keuangan personal digunakan indikator membuat anggaran, pendanaan, alokasi anggaran, pengeluaran dan evaluasi penggunaan uang dengan menggunakan sekala Likert. Hasil dari penelitian ini diketahui bahwa indeks keuangan inklusif masing-masing kota dan kabupaten di Provinsi Jawa Timur berbedabeda. Seluruh wilayah kota mayoritas memiliki 
indeks keuangan inklusif yang tinggi, sedangkan wilayah kabupaten memiliki indeks keuangan inklusif yang rendah. Hasil penelitian ini juga membuktikan bahwa indeks keuangan inklusif berpengaruh positif signifikan terhadap perilaku keuangan personal.

Evi Steelyana (2013) melakukan penelitian tentang peran keuangan inklusif terhadap pengusaha umkm perempuan di Indonesia.. Penelitian menggunakan metode deskripsi kuantitatif. Hasil dari penelitian ini menyimpulkan agar keuangan inklusif dapat dijalankan secara menyeluruh di Indonesia dan dapat berdampak secara signifikan terhadap pengusaha UMKM, khususnya bagi para pengusaha perempuan.

Bintan Badriatul Ummah (2015) menganalisis keuangan inklusif dan pemerataan pendapatan di Indonesia. Metode yang digunakan dalam penelitian ini menggunakan data panel (pooling data). Adapun variabel yang digunakan dalam penelitian ini adalah Indeks Keuangan inklusif sebagai variabel dependen dan variabel independen menggunakan faktor sosial ekonomi (PDRB, pengangguran, melek huruf, rasio gini) serta infrastruktur (rasio jalan, internet dan ponsel). Hasil penelitian menunjukkan bahwa tingkat keuangan inklusif di Indonesia masih tergolong rendah, yang ditunjukkan dengan nilai indeks keuangan inklusif kurang dari 0,3. Hampir seluruh provinsi di Indonesia memiliki tingkat keuangan inklusif rendah, kecuali Jakarta. Dari pendekatan infrastruktur, jumlah pengguna telepon seluler dan internet mempengaruhi positif tingkat keuangan inklusif di Indonesia. Ketimpangan pendapatan dengan keuangan inklusif memiliki hubungan satu arah dimana ketimpangan pendapatan mempengaruhi keuangan inklusif di Indonesia tetapi tidak sebaliknya.

Job Pristine Migap, dkk (2015) melakukan penelitian tentang keuangan inklusif untuk pertumbuhan inklusif menurut perspektif Nigeria. Metode yang digunakan dalam penelitian ini adalah analisa deskriptif. Variabel yang digunakan yaitu Indeks pertumbuhan inklusif dan indikator-indikator keuangan inklusif. Hasil yang diperoleh dari penelitian ini bahwa keuangan inklusif diperlukan untuk pertumbuhan inklusif di Nigeria, peningkatan penyebaran mobile banking dan layanan internet oleh lembaga keuangan meningkatkan akses terhadap perbankan dan layanan jasa keuangan lainnya begitu pula dengan partisipasi aktif dari lembaga pendidikan guna meningkatkan literasi keuangan.

Cletus .O. Akenbor (Ph.D) menganalisis keuangan inklusif dan jebakan kemiskinan di Nigeria. Adapun metode yang digunakan yaitu analisis koefisien korelasi Pearson dan regresi berganda dengan SPSS. Variabel yang digunakan dalam penelitian ini berupa poverty trap yang dihitung dengan GNP per kapita sebagai variabel dependen dan akses ke layanan keuangan, penggunaan jasa keuangan dan kualitas jasa keuangan sebagai variabel independennya. Hasil dari penelitian ini disimpulkan bahwa penggunaan dan kualitas layanan keuangan memiliki hubungan yang signifikan dengan kemiskinan, sementara itu akses ke layanan keuangan tidak memiliki hubungan yang signifikan dengan kemiskinan di Nigeria.

Mandira Sarma (2012) melakukan penelitian mengenai indeks keuangan inklusif guna mengukur inklusifitas sektor keuangan yang menggunakan data dari 94 negara dengan tahun perhitungan 2004-2010. Metode yang digunakan dalam penelitian di analisis dengan data panel. Hasil dalam penelitian tersebut menyebutkan bahwa inkdeks keuangan inklusif dapat digunakan untuk membandingkan tingkat keuangan inklusif di negara yang berbeda dan untuk memantau kemajuan ekonomi sehubungan dengan keuangan inklusif dari waktu ke waktu. Negara yang menerima pendapatan nasional rendah dan menengah ke bawah memiliki indeks keuangan inklusif rendah. Indeks keuangan inklusif menengah atau sedang didominasi oleh negara dengan pendapatan nasional menengah ke atas dan negara yang memiliki pendapatan tinggi, sedangkan indeks keuangan inklusif tinggi didominasi oleh negara yang berpendapatan tinggi pula. Dengan demikian bahwa keuangan inklusif dan pendapatan nasional cenderung bergerak kearah yang sama meskipun ada beberapa perbedaan.

Tujuan penelitian ini adalah untuk menjawab beberapa permasalahan, yaitu:

1. Mengetahui tingkat Keuangan Inklusif di 
Daerah Istimewa Yogyakarta.

2. Mengetahui pengaruh Produk Domestik Regional Bruto terhadap Keuangan Inklusif di Daerah Istimewa Yogyakarta.

3. Mengetahui pengaruh Angka Melek Huruf terhadap Keuangan Inklusif di Daerah Istimewa Yogyakarta.

4. Mengetahui pengaruh Rasio Jalan terhadap Keuangan Inklusif di Daerah Istimewa Yogyakarta.

\section{METODE PENELITIAN}

\section{Jenis dan Sumber Data}

Jenis data yang digunakan dalam penelitian ini adalah data sekunder berupa data time series dan cross section atau lebih dikenal dengan istilah pooling data atau data panel. Data tersebut bersumber dari Bank Indonesia, Badan Pusat Statistik, dan berbagai sumber yang terkait. Periode analisis dalam penelitian ini adalah tahun 2004-2013 dengan cross section dari 4 Kabupaten 1 Kota di Daerah Istimewa Yogyakarta

\section{Teknik Pengumpulan Data}

Teknik pengumpulan data yang digunakan dalam penelitian ini berupa studi kepustakaan atau library research yaitu penelitian yang bahan atau materinya diambil melalui metode kepustakaan berupa tulisan-tulisan artikel ilmiah, majalah, berita, jurnal, penelitian ilmiah lainnya yang memiliki hubungan dengan topik penelitian yang diteliti.

\section{Indeks Keuangan Inklusif}

Indeks keuangan inklusif merupakan ukuran untuk tingkat keuangan inklusif. Indeks keuangan inklusif akan dipergunakan untuk mengukur tingkat keuangan inklusif di 4 kabupaten dan 1 kota madya di Daerah Istimewa Yogyakarta dari tahun 2004 sampai dengan tahun 2013. Perhitungan indeks keuangan inklusif dalam penelitian ini mengikuti konsep perhitungan yang telah dilakukan oleh Sarma (2012), Sanjaya (2014) dan Ummah (2015).

Pengukuran indeks keuangan inklusif mencakup tiga dimensi yaitu dimensi penetrasi perbankan, ketersediaan jasa perbankan dan penggunaan jasa perbankan. Untuk mengetahui indeks dari setiap dimensi (di), dapat dihitung dengan menggunakan persamaan berikut:

d_i $=W \_i\left(A \_i-m \_i\right) /\left(M \_i-m \_i\right) ; i=1,2,3$.

Dimana:

$\mathrm{di}=$ dimensi ke-i $(\mathrm{d} 1=$ penetrasi, $\mathrm{d} 2=$ ketersediaan, $\mathrm{d} 3$ = penggunaan)

$\mathrm{Wi}=$ bobot yang diberikan kepada dimensi kei, $0 \leq \mathrm{W} \_\mathrm{i} \leq 1$

$\mathrm{Ai}=$ nilai aktual dari peubah $\mathrm{i}$

$\mathrm{Mi}=$ nilai maksimum (batas atas) dari peubah $\mathrm{i}$

$\mathrm{mi}=$ nilai minimum (batas bawah) dari peubah i

Sebagaimana dalam penjelasan sebelumnya, dimensi keuangan inklusif yang diukur terdiri dari tiga dimensi. Dimensi yang pertama adalah dimensi penetrasi perbankan yang menggambarkan banyaknya pengguna jasa perbankan. Dimensi kedua adalah ketersediaan jasa perbankan yang menggambarkan jangkauan perbankan kepada masyarakat. Dimensi terakhir adalah kegunaan jasa perbankan yang menggambarkan manfaat jasa perbankan yang diterima masyarakat. untuk mengukur ketiga dimensi tersebut, berikut Indikator yang digunakan dalam penelitian ini dirangkum dalam table 1.

Persamaan (1) akan menghasilkan nilai $0 \leq$ $\mathrm{d} \_\mathrm{i} \leq 1$. Semakin tinggi nilai di maka semakin tinggi pula perolehan daerah pada dimensi i. Apabila terdapat tiga dimensi dari keuangan inklusif yang dihitung, yaitu 1 untuk penetrasi, 2 untuk ketersediaan dan 3 untuk penggunaan, maka perolehan suatu daerah dari dimensi tersebut diinterpretasikan dengan titik $X=(\mathrm{d} 1$, d2, d3) pada ruang 3-dimensi (gambar 3.1). Dalam ruang 3-dimensi, titik $\mathrm{O}=(0,0,0)$ menunjukkan titik kondisi keuangan inklusif yang buruk, sedangkan titik $\mathrm{W}=(\mathrm{W} 1, \mathrm{~W} 2, \mathrm{~W} 3)$ menunjukkan kondisi keungan inklusif yang ideal dari setiap dimensi. 
Tabel 1. Indikator Perhitungan Indeks Keuangan Inklusif

\begin{tabular}{llccc}
\hline \multicolumn{1}{c}{ Dimensi } & \multicolumn{1}{c}{ Indikator } & Bobot & $\begin{array}{c}\text { Batas Bawah } \\
\left(\mathrm{m}_{\mathrm{i}}\right)\end{array}$ & Batas Atas $\left(\mathrm{M}_{\mathrm{i}}\right)$ \\
\hline $\begin{array}{l}\text { Penetrasi Perbankan } \\
\left(\mathrm{d}_{1}\right)\end{array}$ & $\begin{array}{l}\text { Jumlah rekening deposit } \\
\text { dibagi jumlah populasi } \\
\text { dewasa }\end{array}$ & 1 & 0 & 5,008613005 \\
\hline $\begin{array}{l}\text { Ketersediaan Jasa } \\
\text { Perbankan }\left(\mathrm{d}_{2}\right)\end{array}$ & $\begin{array}{l}\text { Jumlah kantor cabang } \\
\text { perbankan dibagi jumlah } \\
\text { populasi dewasa }\end{array}$ & 1 & 0 & 0,0001356253 \\
\hline Kegunaan $\left(\mathrm{d}_{3}\right)$ & $\begin{array}{l}\text { Proporsi kredit dan tabungan } \\
\text { terhadap PDRB }\end{array}$ & 1 & 0 & 6,538161535 \\
\hline
\end{tabular}

Letak titik $\mathrm{X}, \mathrm{O}$, dan $\mathrm{W}$ merupakan faktor penting dalam mengukur tingkat keuangan inklusif. Semakin besar jarak antara titik $O$ dengan titik $X$, semakin tinggi pula tingkat keuangan inklusif. Semakin kecil jarak antara titik $X$ dengan titik $W$, semakin tinggi tingkat keuangan inklusif. Kedua jarak tersebut dinormalisasi dengan jarak antara $\mathrm{W}$ dan $\mathrm{O}$ agar nilainya antara 0 dan 1 . Oleh karena itu, nilai indeks keuangan inklusif akan berada antara 0 dan 1 . Semakin tinggi nilai indeks maka sistem keuangan semakin inklusif.

Indeks keuangan inklusif yang digambarkan dalam ruang tiga dimensi dapat dilihat pada gambar dibawah ini:

Jarak antara titik $O$ dengan titik $X$ dilambangkan dengan $\mathrm{X} 1$, yaitu:

$X \_1=\sqrt{ }\left(\left[\mathrm{d} \_1 \rrbracket^{\wedge} 2+\left[\mathrm{d} \_2 \rrbracket^{\wedge} 2+\llbracket \mathrm{d} \_3 \rrbracket^{\wedge} 2\right) / \sqrt{ }\left(\left[\mathrm{w} \_1 \rrbracket^{\wedge} 2\right.\right.\right.\right.$

$+\llbracket w_{-} 2 \rrbracket^{\wedge} 2+\llbracket\left(w \_3 \rrbracket^{\wedge} 2\right)$

Jarak antara titik $X$ dengan titik $W$ dilambangkan dengan $\mathrm{X} 2$, yaitu:

X_2 $=1-\sqrt{ }\left(\left(\llbracket \mathrm{w} \_1-\mathrm{d} \_1\right) \rrbracket^{\wedge} 2+\llbracket\left(\mathrm{w} \_2-\mathrm{d} \_2\right) \rrbracket^{\wedge} 2+\llbracket\left(\mathrm{w} \_3-\right.\right.$

d_3 $\left.) \rrbracket^{\wedge} 2\right) / \sqrt{ }\left(\left(w_{-} 1 \rrbracket^{\wedge} 2+\left[\left(w \_2 \rrbracket^{\wedge} 2+\llbracket\left(w \_3 \rrbracket^{\wedge} 2\right)\right.\right.\right.\right.$...

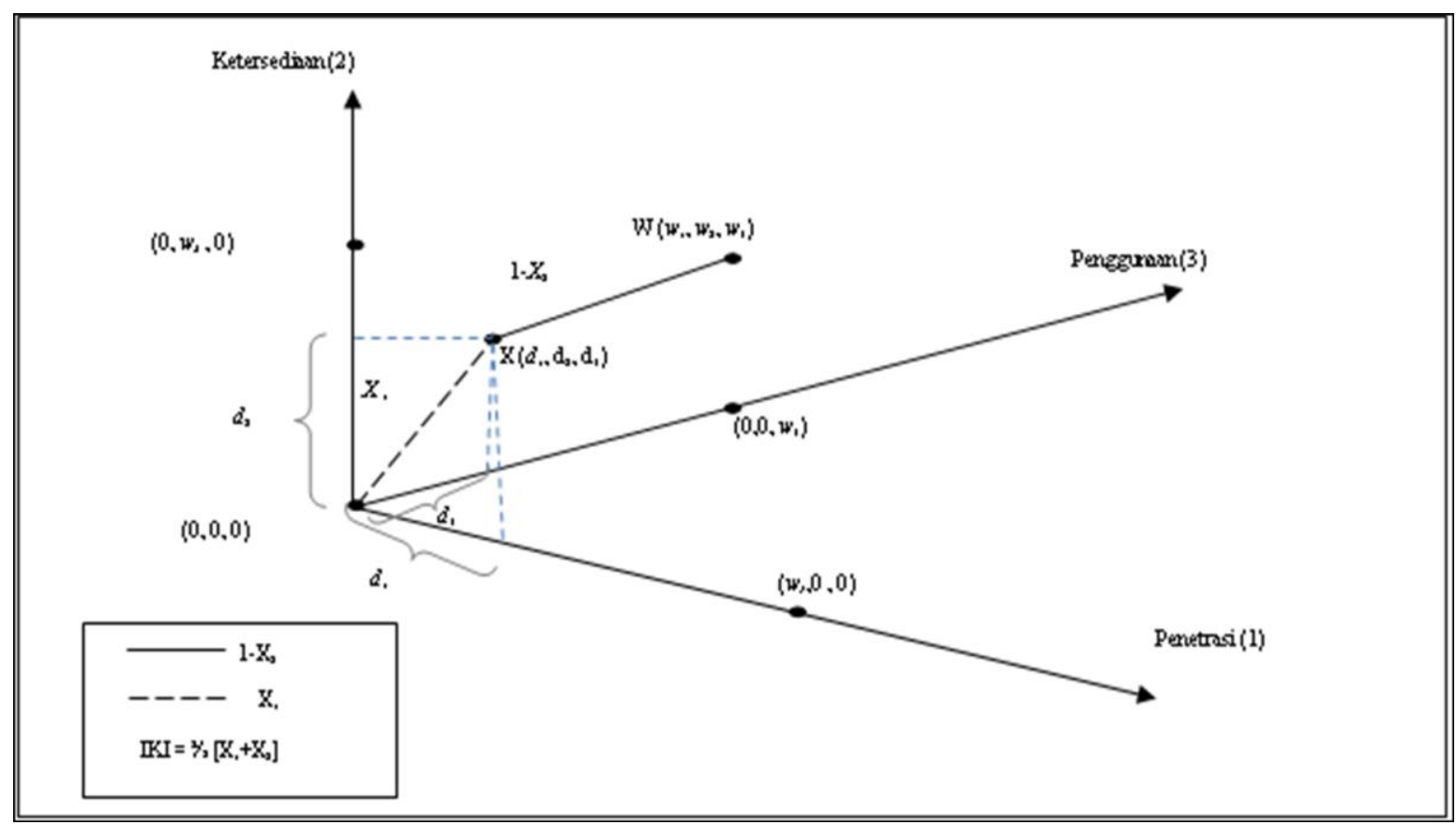

Sumber: Sarma, 2012 (dengan penyesuaian)

Gambar 1. Grafik Tiga Dimensi Indeks Keuangan Inklusif 
Maka nilai indeks keuangan inklusif adalah rata-rata keduanya, yaitu:

$\mathrm{IKI}=1 / 2[\mathrm{X} 1+\mathrm{X} 2]$

Indeks dari keuangan inklusif dari masingmasing daerah dapat dihitung dengan:

$\mathrm{IKI}=1 / 2 \quad\left[\sqrt{ }\left(\mathrm{d} \_1^{\wedge} 2+\mathrm{d} \_2^{\wedge} 2+\mathrm{d} \_3^{\wedge} 2\right) / \sqrt{ } 3+(1-\sqrt{ }((1-\right.$ d_1 $\left.\left.\left.)^{\wedge} 2+\left(\left[1-d \_2\right)\right]^{\wedge} 2+\left(1-d \_3\right)^{\wedge} 2\right) / \sqrt{ } 3\right)\right]$

Nilai indeks keuangan inklusif berada antara 0 dan 1 . Nilaik IKI=1 menunjukkan bahwa daerah tersebut memilik kondisi keuangan inklusif terbaik di antara daerah yang lain. Sedangkan nilai IKI $=0$ menunjukkan daerah tersebut memiliki kondisi keuangan inklusif paling buruk. Tingkat keuangan inklusf semakin baik jika nilai indeks keuangan inklusif mendekati 1. Sarma (2012) menyebutkan bahwa tingkat indeks keuangan inklusif disebut tinggi apabila $0,6<$ IKI $\leq 1$, tingkat keuangan inklusif sedang apabila nilai indeks keuangan inklusif $0,3 \leq$ IKI $\leq 0,6$ dan tingkat keuangan inklusif rendah apabila nilai indeks $<0,3$.

\section{Uji Kualitas Data}

Untuk menguji kualitas data dalam penelitian ini menggunakan uji asumsi klasik. Mengacu pada Basuki dan Yuliadi (2015a: 72) bahwa pada data panel tidak semua uji asumsi klasik yang ada pada metode OLS dipakai, yang diperlukan hanya multikolinieritas dan heteroskedastisitas. Oleh karena itu, untuk menguji kualitas data dalam penelitian ini digunakan uji multikoleniaritas dan uji heteroskedatisitas.

\section{Uji Hipotesis dan Anlisis Data}

Menurut Agus Widarjono (2009) dalam Basuki dan Yuliadi (2015a: 54) penggunaan data panel dalam sebuah observasi mempunyai beberapa keuntungan yang dapat diperoleh. Pertama, data panel yang merupakan gabungan dua data, yaitu time series dan cross section yang mampu menyediakan data lebih banyak sehingga akan lebih menghasilkan degree of freedom yang lebih besar. Kedua, menggabungkan informasi dari data time series dan cross section dapat mengatasi masalah yang timbul ketika ada masalah penghilangan variabel (omitted-variabel).
Meskipun ada beberapa keuntungan yang diperoleh dengan menggunakan data panel, metode ini juga memiliki keterbatasan seperti masalah dalam desain survei panel (cakupan, non-response, recall, frekuensi dan waktu), distorsi kesalah pengamatan yang biasanya terjadi karena ketidaksesuaian respon, masalah selektivitas (Self-selectivity, Non-response, Attrition) dan cross section dependence.

Menurut Basuki dan Yuliadi (2015b: 136), dalam metode estimasi model regresi dengan menggunakan data panel dapat dilakukan melalui tiga pendekatan, antara lain Model Common Effect, Fixed Effect dan Random Effect. Secara umum model regresi data panel adalah sebagai berikut:

$\mathrm{Y}=\mathrm{a}+\mathrm{b} \_1 \mathrm{X} \_1$ it $+\mathrm{b} \_2 \mathrm{X} \_2$ it $+\mathrm{b} \_3 \mathrm{X} \_3 \mathrm{it}+\mathrm{e}$.

Dimana:

$\mathrm{Y}=$ Variabel dependen

$\mathrm{a}=$ Konsanta

$\mathrm{X}=$ Variabel independen $(1,2,3)$

b $(1,2,3)=$ Koefisien regresi masing-masing variable independen

$\mathrm{e}=$ Error term

$\mathrm{t}=$ waktu

$\mathrm{i}=$ daerah

Pemilihan model yang digunakan dalam penelitian dilakukan berdasarkan pertimbangan statistik. Hal ini perlu dilakukan dengan tujuan untuk memperoleh dugaan yang tepat dan efisien. Pertimbangan statistik yang dimaksud adalah: Chow Test, Hausman Test, dan LM Test.

\section{Chow Test}

Beberapa literatur menyebutnya dengan uji F-statistik yang digunakan untuk memilih model apakah menggunakan model Common Effect atau Fixed Effect. Hal ini dilakukan karena asumsi bahwa setiap unit cross-section memiliki prilaku yang sama adalah tidak realistis karena sangat besar kemungkinan setiap unit cross-section memiliki prilaku yang berbeda. Chow-test dilakukan dengan hipotesa statistik sebagai berikut: H0: Common Effect Model atau Pooled OLS H1: Fixed Effect Model 


\section{Hausman Test}

Digunakan sebagai dasar pertimbangan dalam penentuan penggunaan model Fixed Effect atau Random Effect. Penggunaan model fixed effect memiliki kelemahan yaitu hilangnya derajat bebas dengan menggunakan variabel dummy, namun demikian penggunaan model random effect juga harus memperhatikan kebebasan pelanggaran asumsi dari setiap komponen galat. Hausman-test dilakukan dengan hipotesa statistik sebagai berikut:

H0: Model Random Effect

H1: Model Fixed Effect

\section{LM Test}

The Breusch-Pagan LM Test (LM-Test) digunakan sebagai pertimbangan statistik dalam memilih model Random Effect atau Common Effect. Hipotesis statistik yang digunakan adalah sebagai berikut:

H0: Model Common Effect

H1: Model Random Effect

Dasar penolakan hipotesis statistik $\mathrm{H} 0$ adalah dengan menggunakan nilai statistik LM yang mengikuti distribusi chi-square. Statistik LM dihitung dengan menggunakan residual Ordinary Least Square (OLS) yang diperoleh dari hasil estimasi model pooled.

Setelah mendapatkan model terbaik maka untuk menganalisis model dalam penelitian digunakan uji statistik. Uji statistik dalam meliputi uji t-statistik (uji signifikan parameter individual), uji F-statistik (uji signifikansi bersama-sama) dan koefisen determinasi ( $R$ Square).

\section{HASIL DAN PEMBAHASAN}

\section{Uji Kualitas Data}

Berdasarkan hasil uji multikoleniaritas pada penelitian ini, disimpulkan bahwa terdapat multikoleniaritas. Dimana terdapat koefisien korelasi variabel independen $>0,85$, sehingga model ini termasuk modal yang kurang bagus karena terdapat korelasi antara variabel independennya. Syarat model yang baik adalah model yang bebas dari multikoleniaritas. Penyembuhan multikoleniaritas dapat dilakukan dengan menambah atau mengurangi sampel, namun mengurangi satu atau lebih variabel kemungkinan akan membuat model semakin tidak bagus (Hermanto dan Saptutyingsih, 2002). Begitu pula dengan menambah sampel. Sehingga dalam penelitian ini tetap dibiarkan adanya multikoleniaritas.

Hasil uji heterosedastisitas menunjukkan bahwa model ini bebas dari permasalahan varians dari setiap gangguan atau residualnya konstan. Hasil uji heteroskedastisitas dapat dilihat pada tabel berikut:

Tabel 2. Hasil Uji Heteroskedastisitas dengan Uji Park

\begin{tabular}{ccccc}
\hline Variable & Coefficient & Std. Error & t-Statistic & Prob. \\
\hline C & -8.124117 & 10.20577 & -0.796032 & 0.4301 \\
\hline X1 & $2.16 \mathrm{E}-07$ & $2.07 \mathrm{E}-07$ & 1.043250 & 0.3023 \\
\hline X2 & -0.005144 & 0.122031 & -0.042154 & 0.9666 \\
\hline X3 & 0.325307 & 0.208620 & 1.559331 & 0.1258
\end{tabular}

Sumber: data diolah

Dari tabel diats dapai dilihat bahwa nilai probabilitas lebih besar dari $a=0,05$. Sehingga dapat disimpulkan bahwa dalam penelitian ini tidak terdapat heteroskedastisitas dengan kata lain model ini bebas dari heteroskedastisitas.

\section{Hasil Penelitian}

Berdasarkan pemilihan models regresi, maka model regresi yang digunakan dalam penelitian ini adalah model Fixed Effect.
Pemilihan model yang digunakan dalam penelitian dilakukan berdasarkan pertimbangan statistik. Hal ini perlu dilakukan dengan tujuan untuk memperoleh dugaan yang tepat dan efisien. Berikut hasil pemilihan model regresi data panel:

\section{Chow Test}

Pengujian F statistik (Uji Chow) dilakukan dengan melihat hasil uji Likelihood Ratio. Dalam 
pengujian ini, yang diperhatikan adalah probabilitas dari cross section F. Apabila nilai probabilitas untuk cross section $\mathrm{F}>0,05$ (ditentukan di awal sebagai tingkat signifikansi atau alpha) maka $\mathrm{H}_{0}$ diterima dan $\mathrm{H}_{1}$ ditolak.
Berdasarkan hipotesis diatas maka dapat disimpulkan bahwa model yang terpilih adalah common effect, tetapi apabila probabilias cross section $\mathrm{F}<0,05$ maka model yang terpilih adalah fixed effect.

Tabel 3. Hasil Uji Likelihood Ratio

\begin{tabular}{lccc}
\hline \multicolumn{1}{c}{ Effects Test } & Statistic & d.f. & Prob. \\
\hline Cross-section F & 18.285114 & $(4,42)$ & 0.0000 \\
\hline $\begin{array}{l}\text { Cross-section Chi- } \\
\text { square }\end{array}$ & 50.424156 & 4 & 0.0000 \\
\hline
\end{tabular}

Sumber: data diolah

Berdasarkan tebel di atas, dapat diketahui bahwa nilai probabilitas cross-section $\mathrm{F}$ sebesar 0,0000 yang nilainya $<0,05$ sehingga dapat disimpulkan bahwa model fixed effect lebih tepat digunakan dalam penelitian ini disbanding dengan model common effect.

\section{Hausman Test}

Statistik uji Hausman mengikuti distribusi statistik Chi-Squares dengan derajat kebebasan (df) sebesar jumlah variabel bebas. Apabila nilai statistik Hausman lebih besar dari nilai kritis Chi-Squares maka $\mathrm{H}_{0}$ ditolak dan otomatis $\mathrm{H}_{1}$ diterima yang artinya model yang tepat untuk regresi data panel adalah model fixed effect. Sebaliknya, apabila nilai statistik hausman lebih kecil dari nilai kritis Chi-Squares maka $\mathrm{H}_{0}$ diterima dan otomatis $\mathrm{H}_{1}$ ditolak yang artinya model yang tepat untuk regresi data panel adalah model random effect. Berikut hasil Uji Hausman:

Tabel 4. Hasil Uji Hausman

\begin{tabular}{lccc}
\hline Test Summary & Chi-Sq. Statistic & $\begin{array}{c}\text { Chi-Sq. } \\
\text { d.f. }\end{array}$ & Prob. \\
\hline $\begin{array}{l}\text { Cross-section } \\
\text { random }\end{array}$ & 33.493415 & 3 & 0.0000 \\
\hline
\end{tabular}

Sumber: data diolah

Dari di atas dapat di ketahui nilai probabilitas cross section random. Apabila nilainya $>0,05$ maka model yang terpilih adalah random effect, tapi apabila niainya < 0,05 maka model yang terpilih adalah fixed effect. Pada tabel diatas terlihat bahwa nilai prob. cross-section random sebesar 0,0000 yang mana nilainya $<0,05$ sehingga dapat disimpulkan bahwa model fixed effect lebih tepat dibandingkan dengan model random effect digunakan dalam penelitian ini.

Dari dua uji pemilihan model diatas dapat disimpulkan bahwa dalam penelitian ini model Fixed Effect lebih baik dibandingkan dengan model Random Effect dan Common Effect, tanpa peneliti harus melakukan pengujian selanjutnya (LM Tes).

\section{Estimasi Model data Panel}

Berdasarkan pemilihan moel terbaik yang telah dilakukan sebelumnya maka model yang digunakan dalam penelitian ini Fixed Effect Model. Dapat diketahui bahwa masing-masing kabupaten/kota memberikan efek yang berbeda terhadap Keuangan Inklusif di Daerah Istimewa Yogyakarta. Daerah yang memberikan efek terbesar hingga efek terkecil secara berurutan adalah Kota yogyakartakarta memberikan efek sebesar 0,675648858295, kemudian disusul kabupaten Kulonprogo dengan memberikan efek sebesar 0,149153 terhadap keuangan inklusif di Daerah Istimewa Yogyakarta, sementara kabupaten laninnya memberikan efek yang negatif tehadap keuangan inklusif di Daerah Istimewa Yogyakarta, dimana kabupaten Bantul memberikan efek sebesar -0,176049, kabupaten Gunungkidul dengan efek sebesar -0,262527 dan kabupaten sleman yang memberikan efek paling rendah dengan angka sebesar -0,386226. 


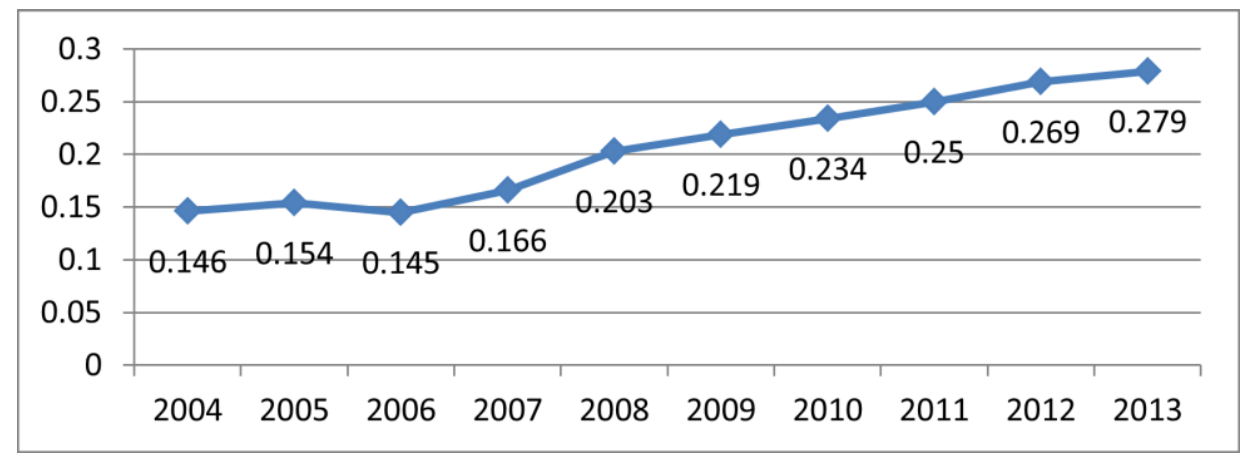

Sumber: Data Diolah

Gambar 3. Indek Keuangan Inklusif di Daerah Istimewa Yogyakarta tahun 2004-2013

\section{Uji Statistik}

Dari hasil penelitian dapat diketahui bahwa koefisien regresi untuk variabel X1 (PDRB) sebesar 1,43E-07 dengan probablitas sebesar 0,0000 yang signifikan pada taraf nyata 5 persen. Dari hasil tersebut dapat diketahui bahwa variabel PDRB berpengaruh positif dan signifikan terhadap Keuangan Inklusif di Daerah Istimewa Yogyakarta, sementara itu variabel X2 (Angka Melek Huruf) memiliki koefisien regresi negatif sebesar 0,025442 dengan probabilitas sebesar 0,0012 yang signifikan pada taraf nyata 5 persen. Dari hasil tersebut dapat disimpulkan bahwa angka melek huruf berpengaruh negatif dan signifikan terhadap Keuangan Inkusif di Daerah Istimewa Yogyakarta.

Hasil uji t-statistik untuk variabel X3 (Rasio Jalan) tidak jauh berbeda dengan hasil regresi variabel X2. Rasio Jalan memiliki koefisien regresi negatif sebesar $-0,040918$ dengan probabilitas sebesar 0,2698 dan tidak signifikan pada taraf nyata 5 persen. Ini berarti Bahwa Rasio Jalan berpengaruh negatif dan tidak signifikan terhadap Keuangan Inkusif di Daerah Istimewa Yogyakarta.

Hasil uji F statisti menunjukkan nilai probabilitas F-statistik yang ditunjukkan model ini adalah sebesar 0,000000. Hal ini berarti bahwa variabel independen secara bersamasama mempengaruhi variabel dependen, dengan kata lain PDRB, Angka Melek Huruf dan Rasio jalan secara bersama-sama mempengaruhi Keuangan Inklusif di Daerah Istimewa Yogyakarta. Dari hasil pengujian didapatkan nilai $\mathrm{R}$ squared sebesar 0,9594647. Hal ini mendakan bahwa model ini mampu menjelaskan variabel dependen sebesar 95,94\%, sedangkan sisanya sebesar $4,06 \%$ dijelaskan oleh variabel lain di luar penelitian ini.

\section{Pembahasan}

Indeks keuangan inklusif dibentuk oleh 3 dimensi yaitu penetrasi perbankan, ketersediaan jasa perbankan, dan penggunaan jasa perbankan. Nilai indeks keuangan inklusif dari empat kabupaten dan satu kota madya yang terdapat di Daerah Istimewa Yogyakarta dari tahun 2004 sampai dengan 2013 menujukkan angka $<0,3$ dan tergolong rendah, meskipun terdapat satu kota yang nilainya $\geq 0,6$ yaitu kota yogyakartakartakarta. Pada umumnya nilai indeks keuangan inklusif dari tahun 2004-2013 selalu mengalami peningkatan tetapi peningkatan nilai indeks tidak begitu signifikan. Pada tahun 2004 nilai indeks keuangan inklusif Daerah Istimewa Yogyakarta mencapai 0,146 dan meningkat menjadi 0,279 pada tahun 2013.

Adanya peningkatan keuangan inklusif di Daerah istimewa Yogyakarta, khususnya jasa perbankan, dikarenakan adanya peningkatan dari setiap dimensi keuangan inklusif yaitu penetrasi perbankan, ketersediaan perbankan, dan penggunaan jasa perbankan di Daerah Istimewa Yogyakarta. Peningkatan ini juga menggambarkan bahwa akses dan penggunakan jasa perbankan oleh masyarakat, khususnya bank umum konvensional, mengalami peningkatan. Hal ini seiring dengan semakin berkembangnya sektor perbankan di Daerah Istimewa Yogyakarta.

Mengadopsi dari penelitian Sarma (2012), dalam penelitian ini, masing-masing dimensi 
dibagi kedalam 3 kategori, yaitu tinggi $(0,6<d$ $\leq 1)$, sedang $(0,3 \leq d \leq 0,6)$, dan rendah $(<0,3)$. Dari data diatas dapat diketahui bahwa dimensi ketersediaan jasa perbankan di Daerah Istimewa Yogyakarta paling kecil jika dibandingkan dengan dimensi penetrasi dan kegunaan, yaitu dengan rata-rata sebesar 0,1. Dimensi ketersediaan jasa perbankan juga tergolong rendah, artinya bahwa meskipun jumlah kantor cabang yang ada di Daerah Istimewa Yogyakarta pada tahun 2013 mencapai 54 unit, tetapi jumlah kantor cabang yang telah ada ini belum mampu melayani seluruh masyarakat di Daerah Istimewa Yogyakarta. Dari 100.000 populasi dewasa yang ada di Daerah Istimewa Yogyakarta hanya dilayani oleh 2 kantor cabang bank umum konvensional.

Tabel 5.

Nilai Dimensi Indeks Keuangan Inklusif di Daerah Istimewa Yogyakarta tahun 2004-2013 Dimensi Indeks Keuangan inklusif

\begin{tabular}{cccc} 
Tahun & $\begin{array}{c}\text { Penetrasi } \\
\text { Perbankan }\end{array}$ & $\begin{array}{c}\text { Ketersediaan Jasa } \\
\text { Perbankan }\end{array}$ & $\begin{array}{c}\text { Penggunaan Jasa } \\
\text { Perbankan }\end{array}$ \\
\hline 2004 & 0.174 & 0.122 & 0.139 \\
\hline 2005 & 0.177 & 0.119 & 0.163 \\
\hline 2006 & 0.137 & 0.117 & 0.177 \\
\hline 2007 & 0.169 & 0.118 & 0.204 \\
\hline 2008 & 0.253 & 0.145 & 0.207 \\
\hline 2009 & 0.253 & 0.163 & 0.238 \\
\hline 2010 & 0.253 & 0.180 & 0.267 \\
\hline 2011 & 0.254 & 0.183 & 0.308 \\
\hline 2012 & 0.254 & 0.188 & 0.355 \\
\hline 2013 & 0.254 & 0.183 & 0.388 \\
\hline
\end{tabular}

Sumber: data diolah

Dimensi penetrasi perbankan di Daerah Istimewa Yogyakarta juga tergolong rendah karena nilai dimensi ini berkisar antara 0,1-0,2. Hal ini berarti meskipun jumlah rekening di Daerah Istimewa Yogyakarta mencapai 2,7 juta unit, orang yang mengakses jasa perbankan di Daerah Istimewa Yogyakarta masih rendah. Dari 100.000 populasi dewasa di Daerah Istimewa Yogyakarta terdapat 127 ribu orang yang memilik rekening di bank umum konensional pada tahun 2013. Sama halnya dengan dimensi penetrasi dan ketersediaan, dimensi kegunaan juga tergolong dalam kategori rendah. Meskipun terjadi peningkatan yang relatif lebih besar dari tahun 2004 sebesar 0,1 menjadi 0,3 pada tahun 2013. Peningkatan pada dimensi kegunaan ini menunjukkan adanya peningkatan pada volume tabungan yang dihimpun dan kredit yang disalukan oleh bank umum konvensional terhadap PDRB di Daerah Istimewa Yogyakarta.

Dimensi ketersediaan perbankan lebih rendah dibandingkan dengan dimensi penetrasi perbankan. Hal ini menandakan bahwa, jumlah kantor cabang bank umum konvensional relatif lebih sedikit tetapi jumlah orang yang memiliki rekening lebih banyak. Rendahnya dimensi ketersediaan dapat disebabkan oleh kondisi geografis dan demografis Daerah Istimewa Yogyakarta yang cenderung kecil dan dikelilingi perbukitan, namum padat penduduk. Daerah Istimewa Yogyakarta yang dikenal sebagai kota pelajar dimana setiap tahun mendapatkan sumbangan pelajar/mahasiswa yang tidak sedikit dari seluruh Indonesia. Pelajar/mahasiswa juga membutuhkan layanan jasa keuangan, Namun hal tersebut tidak diimbangi dengan pertumbuhan kantor pelayanan jasa keuangan. Menurut Ummah (2015) rendahnya penetrasi perbankan dapat disebabkan oleh beberapa kemungkinan. Pertama, meskipun perbankan memiliki banyak nasabah, namun melakukan transaksi dengan volume yang relatif kecil. Besarnya transaksi dapat dilihat pada dimensi ketiga yaitu dimensi kegunaan. Kedua, pemberian bobot yang sama dalam perhitungan indeks dimensi. Penetrasi perbankan 
seharusnya diberi bobot yang lebih besar dibanding dengan dimensi lainnya. Hal ini karena jumlah pengguna perbankan merupakan indikator penting dari jasa keuangan yang inklusif. Jasa keuangan akan semakin inklusif apabila penggunaan jasa keuangan tersebut semakin banyak.

Rendahnya tingkat keuangan inklusif di Daerah Istimewa Yogyakarta dapat disebabkan oleh banyaknya penduduk yang tidak dapat mengakses layanan jasa perbankan. Masyarakat tidak dapat mengakses perbankan karena adanya hambatan geografis Daerah Istimewa Yogyakarta yang merupakan daerah dengan kondisi perbukitan atau tidak rata sehingga biaya pendirian kantor cabang mahal. Selain itu, persyaratan yang ketat, proses yang kompleks, dan formalitas yang tinggi menjadi hambatan bagi masyarakat untuk mengakses perbankan (Ummah, 2015).

Perbedaan indeks keuangan inklusif antar kabupaten/kota di Daerah Istimewa Yogyakarta menunjukkan masih terjadinya ketimpangan akses jasa perbankan antar kabupaten/kota. Selain itu, beberapa kabupaten/kota yang memiliki kantor perbankan, rekening deposit, dan tingkat penggunaan perbankan yang cukup tinggi memiliki indeks keuangan inklusif lebih rendah dibandingkan dengan kabupaten/kota yang memiliki kantor perbankan, rekening deposit, dan tingkat penggunaan perbankan yang relatif lebih rendah. Berikut indeks keuangan inklusif berdasarkan kabupaten/kota di Daerah Istimewa Yogyakarta.

Tabel 6.

Indeks Keuangan Inklusif berdasarkan Kabupaten/kota di Daerah Istimewa Yogyakarta tahun 2004-2013

\begin{tabular}{ccccccc}
\hline Daerah & Kulonprogo & Bantul & Gunungkidul & Sleman & $\begin{array}{c}\text { Kota } \\
\text { Yogyakarta }\end{array}$ & $\begin{array}{c}\text { Prov. } \\
\text { DIY }\end{array}$ \\
\hline 2004 & 0.084 & 0.074 & 0.095 & 0.069 & 0.531 & 0.146 \\
\hline 2005 & 0.086 & 0.066 & 0.046 & 0.099 & 0.538 & 0.154 \\
\hline 2006 & 0.089 & 0.077 & 0.050 & 0.089 & 0.484 & 0.145 \\
\hline 2007 & 0.092 & 0.079 & 0.049 & 0.103 & 0.549 & 0.166 \\
\hline 2008 & 0.072 & 0.039 & 0.039 & 0.083 & 0.586 & 0.203 \\
\hline 2009 & 0.075 & 0.043 & 0.042 & 0.097 & 0.639 & 0.219 \\
\hline 2010 & 0.096 & 0.064 & 0.053 & 0.122 & 0.817 & 0.234 \\
\hline 2011 & 0.098 & 0.068 & 0.057 & 0.132 & 0.869 & 0.250 \\
\hline 2012 & 0.100 & 0.067 & 0.062 & 0.137 & 0.938 & 0.269 \\
\hline 2013 & 0.123 & 0.079 & 0.082 & 0.159 & 0.978 & 0.279 \\
\hline Rata-rata & $\mathbf{0 . 0 9 2}$ & $\mathbf{0 . 0 6 6}$ & $\mathbf{0 . 0 5 8}$ & $\mathbf{0 . 1 0 9}$ & $\mathbf{0 . 6 9 3}$ & $\mathbf{0 . 2 0 6}$ \\
\hline
\end{tabular}

Sumber: Data diolah

Faktor-faktor yang Mempengaruhi Keuangan Inklusif di DIY

Berdasarkan penelitian maka dapat diketahui bahwa variabel PDRB berpengaruh positif dan signifikan terhadap keuangan inklusif di Daerah Istimewa Yogyakarta. Hasil ini sejalan dengan penelitian Sarma (2012), Migap, dkk (2015)serta Ummah (2015) yang menunjukkan bahwa ukuran perekonomian dalam hal ini Produk Domestik Regional Bruto (PDRB) berpengaruh positif terhadap keuangan inklusif.

Seluruh daerah kabupaten/kota di Daerah Istimewa Yogyakarta memiliki tren PDRB yang meningkat dari tahun 2004 sampai tahun 2013. Hal ini juga mengakibatkan PDRB Daerah Istimewa Yogyakarta selalu mengalami pertumbuhan positif dari tahun ke tahun. Begitu pula dengan tingkat keuangan inklusif setiap daerah kabupaten/kota dari tahun 2004 sampai 2013 selalu mengalami peningkatan. Hal ini menunjukkan bahwa seiring dengan 
peningkatan ukuran perekonomian, keuangan inklusif di Daerah Istimewa Yogyakarta juga meningkat.

Angka melek huruf berpengaruh negatif dan signifikan terhadap keuangan inklusif. Hasil ini berbeda dengan penelitian Ummah (2015) yang menunjukkan bahwa Angka Melek Huruf berpengaruh positif namun tidak signifikan terhadap keuangan inklusif. Angka melek huruf di Daerah Istimewa Yogyakarta terus meningkat dari tahun ke tahun. Daerah yang memiliki Angka Melek Huruf tertinggi adalah Kota yogyakartakarta, sedangkan daerah yang Angka Melek Huruf masih rendah adalah Gunungkidul. Hasil penelitian ini menandakan bahwa angka melek huruf yang tinggi tidak berpengaruh terhadap keuangan inklusif. Hal ini bisa dikerenakan masyarakat yang bisa membaca dan menulis (melek huruf) memiliki tingkat pendidikan yang masih rendah. Sanjaya (2014) menyebutkan bahwa pendidikan berperan penting tidak hanya dalam pertumbuhan ekonomi, tetapi juga dalam perbaikan kesenjangan sosial. Pendidikan yang lebih baik akan meningkatkan keadilan sosial dan pertumbuhan ekonomi. Pendidikan juga berperan dalam pengentasan kemiskinan dengan cara meningkatkan keterampilan dan produktivitas masyarakat. Oleh karena itu, kemampuan individu untuk mengakses perbankan tidak serta merta ditentukan oleh kemampuan membaca menulis, namun lebih kepada keinginan individu terkait untuk ikut andil dalam lembaga keuangan.

Rasio Jalan berpengaruh negatif dan tidak signifikan terhadap keuangan inklusif di Daerah Istimewa Yoyakarta. Hasil ini sesuai dengan penelitian Ummah (2015) yang menyatakan bahwa rasio panjang jalan tidak berpengaruh terhadap keuangan inklusif di Indonesia. Hal ini dikarenakan berkembangnya produk baru yang ditawarkan oleh lembaga keuangan dengan mengembangkan Branchless Banking seperti pengadaan ATM dan mesin setor tunai, pengadaan internet banking dan mobile banking. Kriteria Branchless Banking antara lain yaitu tanpa melalui kantor cabang bank, menggunakan agen yang bekerjasama dengan bank, nasabah bisa melakukan transaksi sendiri atau menggunakan agen, fitur transaksi yang sederhana (basic feature), layanan murah (low cost transaction) dan yang paling utama yaitu ditujukan khususnya untuk segmen bawah atau unbanked poor. Dengan demikian masyarakat tidak harus bersentuhan langsung dengan lembaga keuangan ketika melakukan transaksi.

\section{SIMPULAN DAN SARAN}

\section{Simpulan}

Berdasarkan hasil yang didapatkan dari penelitian yang dilakukan terhadap keuangan inklusif di Daerah Istimewa Yogyakarta adalah sebagai berikut:

1. Hampir seluruh daerah kabupaten/kota di Indonesia memiliki tingkat keuangan inklusif rendah. Rata-rata indeks keuangan inklusif antar daerah kabupaten/kota di Daerah Istimewa Yogyakarta berkisar antara 0,05-0,1, kecuali kota yogyakarta yang tergolong tinggi yang mencapai 0,693. Hal ini disebabkan karena kota yogyakarta merupakan ibu kota provinsi dan pusat kegiatan perekonomian dan pembelajaran.

2. Produk Domestik Regional Bruto berpengaruh positif dan signifikan terhadap tingkat keuangan inklusif di Daerah Istimewa Yogyakarta. Karena semakin tinggi pertumbuhan ekonomi akan semakin meningkatkan kemampuan masyarakat untuk mengakses lembaga keuangan.

3. Angka melek huruf berpengaruh negatif dan signifikan terhadap tingkat keuangan inklusif di Daerah Istimewa Yogyakarta. Kemampuan individu untuk mengakses perbankan tidak serta merta ditentukan oleh kemampuan membaca menulis, namun lebih kepada keinginan individu terkait untuk ikut andil dalam lembaga keuangan.

4. Rasio jalan berpengaruh negatif dan signifikan terhadap tingkat keuangan inklusif di Daerah Istimewa Yogyakarta. Kondisi jalan yang ada saat ini tidak berpengaruh kepada keuangan inklusif. Karena banyak produk perbankan yang telah diterbitkan yang mempermudah akses nasabah tanpa harus bersentuhan langsung dengan perbankan. Seperti halnya peluncuran mobile banking yang tidak 
mengharuskan nasabah untuk mendatangi lembaga keuangan ketika melakukan transaksi.

\section{Saran}

Saran yang dapat diberikan oleh peneliti pada penelitian ini, yaitu sebagai berikut:

1. Baik pemerintah maupun pelaku sektor perbankan bekerja sama untuk meningkatkan akses dan penggunaan jasa perbankan yaitu dengan meningkatkan setiap dimensi keuangan inklusif. Penetrasi perbankan dapat ditingkatkan dengan mengajak masyarakat untuk menabung. Akses perbankan dapat ditingkatkan dengan mengembangkan branchless banking seperti pengadaan ATM dan mesin setor tunai serta mobile banking. Sedangkan untuk dimensi kegunaan, baik pemerintah, Bank Indonesia, serta stakeholder terkait dapat menyediakan kredit murah dan mudah diakses oleh pengusaha kecil yang membutuhkan modal.

2. Perkembangan perekonomian harus ditingkatkan, karena merupakan salah satu faktor yang mempengaruhi keuangan inklusif suatu daerah.

3. Sebagaimana yang tercantum dalam Strategi Nasional Keuangan Inklusif pilar yang pertama yaitu edukasi keuangan. Peningkatan pemahaman terkait jasa perbankan dengan melakukan edukasi jasa keuangan terutama bagi masyarakat yang berpendapatan rendah, perempuan, dan penduduk daerah tertinggal serta peningkatan infrastruktur fisik agar jasa keuangan dapat menjangkau masyarakat di berbagi daerah. Seperti yang terpapar dalam Strategi Nasional Keuangan Inklusif.

4. Pemanfaatan teknologi terutama telepon seluler dan internet secara efisien dapat memperluas jaringan jasa perbankan yang merata ke berbagai daerah dengan mengurangi hambatan geografis (misalnya, mobile money untuk memfasilitasi transfer dan transaksi pembayaran antar pulau, serta antar perdesaan dan perkotaan).

\section{DAFTAR PUSTAKA}

Anonym, Part 7: Uji Asumsi Klasik Regresi Data Panel Dengan Eviews (Multikolinearitas), http://egienews.blogspot.co.id/2013/06/part7-uji-asumsi-klasik-regresi-data.html, Diakses pada 20 November 2015 pk 10.58 WIB.

Akenbor, C.O., 2015, "Financial Inclusion And Poverty Trap In Nigeria", Mustang Journal of Accounting And Finance, Volume 7, Spring, 2015: 149-159.

Ariyoso, 2010, “Operasionalisasi Regresi Data Panel", $\quad$ https://ariyoso.wordpress. com/2010/01/17/regresi-data-panel/,

Diakses pada 16 November 2015 pk 11. 34 WIB.

Badan Pusat Statistik, Daerah Istimewa Yogyakarta dalam Angka.

Basuki, A.T., 2014, Bahan Ajar Ekonometrika.

Basuki, A.T dan Yuliadi, I., 2015, Elektronik Data Processing (SPSS dan Eviews 7), Danisa Media, Yogyakarta.

Ekonometrika

Teori dan Aplikasi, Mitra Pustaka Nurani (MATAN), Yogyakarta.

Bank Indonesia, "Laporan Perkembangan Perekonomian Daerah Istimewa Yogyakarta Kuartal IV". 2014, "Financial Literacy Baseline Survey Summary", Volume 1, September, hal. 1-3. Booklet Keuangan Inklusif 2014.

BPS dan BAPPEDA, 2014, Analisis PDRB DIY 2009-2013.

Endri, Model regresi Panel Data dan Aplikasi Eviews.

Hakim, A.R., Hand Out Panel Data, disampaikan pada kuliah asisten PPIE FE UI TA 2013/2014.

Hermanto dan Saptutyningsih. E, 2002, Processing SPSS 10.0 dan Eviews 3.0, Unit Penerbit Fakultas Ekonomi Universitas Muhammadiyah Yogyakarta, Yogyakarta.

Imboden, K., 2005. “Building inclusive financial sectors: The road to growth and poverty reduction". Journal of International Affairs, 58(2), 65.

Irmawati dan Setyani, 2013, "Model Inklusi Keuangan Pada UMKM Berbasis 
Pedesaan", Jejak Journal of Economics and Policy 6 (2) (2013): 103-213.

Iqbal, M., 2015, Regresi Data Panel (2) "Tahap Analisis", https://dosen.perbanas. id/regresi-data-panel-2-tahap-analisis/, Diakses tanggal 20 November 2015 pk 10. 39 WIB.

Koker, L. de., 2011, “Aligning anti-money laundering, combating of financing of terror and financial inclusion (Questions to consider when FATF standards are clarified)". Journal of Financial Crime Vol. 18 No. 4, 2011 pp. 361-386.

Kurniawan, A., 2014, Modul Praktikum Ekonometrika dan Statistika, universitas Diponegoro.

Migap, J.P., dkk., 2015, “Financial Inclusion For Inclusive Growth: The Nigerian Perspective", International Journal of Information Technology and Business Management, Vol.37 No.1, 29 Mei.

Sanjaya, I.M., 2014, "Inklusi Keuangan Dan Pertumbuhan Inklusif Sebagai Strategi Pengentasan Kemiskinan Di Indonesia", Tesis, Institut Pertanian Bogor.

Sarma, M., 2012, " Index of Financial Inclusion A Measure of Financial Sector Inclusiveness", Berlin Working Paper On Money, Finance, Trade and development, Working Paper No. 07/2012.

Saruparia, C., 2012, "Financial Inclusion for Inclusive Growth in India". Assistant Professor, Faculty of Policy Science, National Law University, Jodhpur.

Sekretariat Negara Republik Indonesia, ASEAN Financial Inclusion, http://www.setneg.go.id/index.php? option $=$ com_contentEtask $=$ viewE $i d=8186$. Diakses tanggal 20 September 2015 pk 15.41 WIB.

Setiawan, M.A., 2015, "Analisis Keterkaitan Inklusi Keuangan Terhadap Perilaku Keuangan Personal Masyarakat Di Wilayah Kota Dan Kabupaten Provinsi Jawa Timur".

Steelyana, E., 2013, "Perempuan dan Perbankan: Sebuah Tinjauan Tentang Peran Inklusi Keuangan Terhadap Pengusaha Umkm Perempuan Di Indonesia", Journal The Winners, Vol. 14 No. 2, September 2013: 95-103.

Suhaimi, U., 2010, Melek Huruf, melek Statistik dan Peradaban. http://uzairsuhaimi. files.wordpress.

com//2010/04/melekhuruf.statistik.pdf,

Diakses tanggal 14 November 2015 pk 09.48 .

Supartoyo, Y.H. dan Kasmiati, Branchless Banking Mewujudkan Keuangan Inklusif sebagai Alternatif Solusi Inovatif Menanggulangi Kemiskinan: Review dan Rekomendasi, https://www.academia.edu/4766290/Branch less_Banking_Mewujudkan_Keuangan_Ink lusif_Sebagai

_Alternatif_Solusi_Inovatif_Menanggulang i_Kemiskinan, Diakses tanggal 1 Oktober 2015 pk 12.53 WIB.

Ummah, B.B., 2015, “Analisis Inklusi Keuangan dan Pemerataan Pendapatan di Indonesia", Tesis, Institut Pertanian Bogor.

Winarno, W.W., 2011, Analisis Ekonometrika dan Statistika dengan Eviews, Edisi 3, UPP STIM YKPN, Yogyakarta. 